\title{
Carboxydobrachium pacificum gen. nov., sp. nov., a new anaerobic, thermophilic, CO- utilizing marine bacterium from Okinawa Trough
}

\author{
T. G. Sokolova, ${ }^{1}$ J. M. González, ${ }^{2}$ N. A. Kostrikina, ${ }^{1}$ N. A. Chernyh, ${ }^{1}$ \\ T. P. Tourova, ${ }^{1}$ C. Kato, ${ }^{3}$ E. A. Bonch-Osmolovskaya ${ }^{1}$ and F. T. Robb ${ }^{2}$
}

Author for correspondence: T. G. Sokolova. Tel: +7 095135 4458. Fax: +7 0951356530. e-mail: sokolova@inmi.host.ru

1 Institute of Microbiology, Russian Academy of Sciences, Prospekt 60 Let Oktyabrya, 7/2, Moscow, 117811, Russia

2 COMB, Columbus Center, 701 E Pratt St, Baltimore, MD 21202, USA

3 The Deepstar Group, Japan Marine Science and Technology Center, Yokosuka 237, Japan

\begin{abstract}
A new anaerobic, thermophilic, CO-utilizing marine bacterium, strain $\mathrm{JM}^{\mathrm{T}}$, was isolated from a submarine hot vent in Okinawa Trough. Cells of strain $\mathrm{JM}^{\top}$ were non-motile thin straight rods, sometimes branching, with a cell wall of the Gram-positive type, surrounded with an S-layer. Chains of three to five cells were often observed. The isolate grew chemolithotrophically on $\mathrm{CO}$, producing equimolar quantities of $\mathrm{H}_{2}$ and $\mathrm{CO}_{2}$ (according to the equation $\left.\mathrm{CO}+\mathrm{H}_{2} \mathrm{O} \rightarrow \mathrm{CO}_{2}+\mathrm{H}_{2}\right)$ and organotrophically on peptone, yeast extract, starch, cellobiose, glucose, galactose, fructose and pyruvate, producing $\mathrm{H}_{2}$, acetate and $\mathrm{CO}_{2}$. Growth was observed from 50 to $80^{\circ} \mathrm{C}$ with an optimum at $70^{\circ} \mathrm{C}$. The optimum pH was 6.8-7.1. The optimum concentration of sea salts in the medium was 20.5-25.5 $\mathrm{g} \mathrm{I}^{-1}$. The generation time under optimal conditions was 7.1 h. The DNA G+C content was $33 \mathrm{~mol} \%$. Growth of isolate $\mathrm{JM}^{\mathrm{T}}$ was not inhibited by penicillin, but ampicillin, streptomycin, kanamycin and neomycin completely inhibited growth. The results of $16 \mathrm{~S}$ rDNA sequence analysis revealed that strain $\mathrm{JM}^{\top}$ belongs to the Thermoanaerobacter phylogenetic group within the Bacillus-Clostridium subphylum of Gram-positive bacteria but represents a separate branch of this group. On the basis of morphological and physiological features and phylogenetic data, this isolate should be assigned to a new genus, for which the name Carboxydobrachium is proposed. The type species is Carboxydobrachium pacificum; the type strain is $\mathrm{JM}^{\top}$ (= DSM 12653').
\end{abstract}

Keywords: submarine hot vents, carbon monoxide utilization, thermophilic anaerobe, Carboxydobrachium pacificum

\section{INTRODUCTION}

Deep-sea hydrothermal fields are inhabited by unique microbial communities that rely on the energy of reduced inorganic compounds of volcanic origin (Jannasch, 1995). Many thermophilic prokaryotes have been isolated from such habitats over the past decade (Prieur et al., 1995). However, most of these organisms were hyperthermophilic archaea of the Euryarchaeota and Crenarchaeota kingdoms. Among them were methanogens of genera Methanopyrus (Kurr et al., 1991) and Methanococcus (Jones et al., 1983; Jeanthon et al., 1998); sulfate and/or sulfite

The GenBank accession number for the $16 \mathrm{~S}$ rDNA sequence of strain $\mathrm{JM}^{\top}$ is AF174484. reducers of the genus Archaeoglobus (Burggraf et al., 1990; Huber et al., 1997); Pyrolobus fumarii, oxidizing molecular hydrogen either aerobically or via nitrate reduction (Blöchl et al., 1997); and numerous anaerobic organotrophs belonging to the genera Staphylothermus (Fiala et al., 1986), Thermococcus (Kobayshi et al., 1994; González et al., 1995, etc.), Pyrococcus (Erauso et al., 1993; González et al., 1998) and Pyrodictium (Pley et al., 1991). The information on the presence of thermophilic bacteria in the microbial communities of deep-sea hot vents is up to now much more sparse. The presence of organotrophic anaerobes and aerobes belonging to the genera Thermotoga, Thermus and Bacillus in deep-sea hydrothermal habitats has been reported (Marteinsson et al., 1995, 1996a, b), but only Thermosipho melan- 
esiensis has been isolated in pure culture (Antoine et al., 1997). The only lithotrophic thermophilic bacterium found in hydrothermal fields of East Pacific Rise is Desulfurobacterium thermolithotrophum (L'Haridon et al., 1998). This extremely thermophilic organism obtains energy for growth from anaerobic oxidation of molecular hydrogen coupled with the reduction of elemental sulfur. In this publication, we describe a new anaerobic thermophilic bacterium isolated from a deep-sea hydrothermal system, which is capable of lithotrophic growth on $\mathrm{CO}$ with the production of molecular hydrogen.

\section{METHODS}

Sampling. Hydrothermal vent samples were collected during a scientific cruise on board the Natsushima research vessel. The manned Shinkai 2000 submersible was used for sample collection. In this study, mud samples were collected from an area with hydrothermal vent activity at the Okinawa Trough $\left(27^{\circ} 33^{\prime} \mathrm{N}, 126^{\circ} 56^{\prime} \mathrm{E}\right)$ at $1395 \mathrm{~m}$ depth. This sampling site has been described by Sakai et al. (1990). Hot vent fluids at this location had a temperature of $110-130^{\circ} \mathrm{C}$ as measured by a thermistor probe inserted into the vent opening. Densely populated colonies of invertebrates can be found around the vents and several thermophilic archaea have been previously isolated from this deep-sea location (Kobayashi et al., 1994).

Enrichment and isolation. For enrichments and cultures, unless otherwise mentioned, Medium 1 was used, which contained $\left(1^{-1}\right): \mathrm{NaCl}, 18 \mathrm{~g} ; \mathrm{KCl}, 0.7 \mathrm{~g} ; \mathrm{MgSO}_{4} .7 \mathrm{H}_{2} \mathrm{O}, 3.9 \mathrm{~g}$; $\mathrm{CaCl}_{2} .2 \mathrm{H}_{2} \mathrm{O}, 0.4 \mathrm{~g} ; \quad \mathrm{NH}_{4} \mathrm{Cl}, 0.3 \mathrm{~g} ; \mathrm{Na}_{2} \mathrm{HPO}_{4}, 0.15 \mathrm{~g}$; $\mathrm{Na}_{2} \mathrm{SiO}_{3}, 0.03 \mathrm{~g}$; trace element solution (Pfennig \& Lippert, 1966), $1 \mathrm{ml}$; vitamin solution (Wolin et al., 1963), $1 \mathrm{ml}$; resazurin, $1 \mathrm{mg} ; \mathrm{NaHCO}_{3}, 0.5 \mathrm{~g} ; \mathrm{Na}_{2} \mathrm{~S} .9 \mathrm{H}_{2} \mathrm{O}, 0.5 \mathrm{~g}$; cysteine $/ \mathrm{HCl}, 0.5 \mathrm{~g}$. The medium was prepared anaerobically. It was supplemented with $0.05 \mathrm{~g}$ yeast extract $1^{-1} \cdot \mathrm{pH}$ was adjusted to $7 \cdot 0-7 \cdot 2$ by the addition of $6 \mathrm{M} \mathrm{HCl}$. Portions of the medium $(10 \mathrm{ml})$ were placed into $50 \mathrm{ml}$ bottles under the flow of oxygen-free nitrogen. Then the gas phase was changed to $\mathrm{CO}$ at $100-110 \mathrm{kPa}$; the bottles were tightly stoppered and sterilized at $120^{\circ} \mathrm{C}$.

To obtain enrichments of CO-utilizing anaerobes, bottles inoculated with mud samples $\left(2 \mathrm{~cm}^{3}\right)$ were incubated at 55 , 60,70 or $80^{\circ} \mathrm{C}$. Growth was determined using light microscopy and GLC detection of CO utilization and formation of gaseous growth products.

Colonies were obtained on Medium 1 solidified by $5 \%$ agar in roll-tubes with $\mathrm{CO}$ as the gas phase. Large-scale cultures were grown at $70{ }^{\circ} \mathrm{C}$ in a Biostat fermenter equipped with a gas recirculation system.

Morphological and ultrastructural studies. Cell morphology was studied using an MBI-11 light microscope and a JEM100 electron microscope. Electron microscopic methods have been previously described (Svetlichny et al., 1991a).

Physiological tests. Potential substrates for growth were tested at a concentration of $0.5 \%(\mathrm{w} / \mathrm{v})$ in the same liquid medium under a $\mathrm{N}_{2}$ atmosphere. Potential electron acceptors were added at $0.2 \%(\mathrm{w} / \mathrm{v})$, except for elemental sulfur, which was added at $1 \%(\mathrm{w} / \mathrm{v})$. Growth was detected using phase-contrast microscopy.

The influence of salts on growth was tested by varying the $\mathrm{NaCl}$ concentration from 0 to $5 \%(\mathrm{w} / \mathrm{v})$ in the Medium 1 supplemented with $0 \cdot 2 \mathrm{~g}$ yeast extract $1^{-1}$ under a $\mathrm{CO}$ gas phase. To determine whether $\mathrm{NaCl}$ can replace artificial seawater, various concentrations of $\mathrm{NaCl}$, from 0.5 to $5 \%$ (w/v), were added to Medium 2, which contained $\left(1^{-1}\right)$ : $\mathrm{NH}_{4} \mathrm{Cl}, 0.066 \mathrm{~g} ; \mathrm{MgCl}_{2} \cdot 6 \mathrm{H}_{2} \mathrm{O}, 0.016 \mathrm{~g} ; \mathrm{CaCl}_{2} .2 \mathrm{H}_{2} \mathrm{O}$, $0.010 \mathrm{~g} ; \mathrm{KCl}, 0.033 \mathrm{~g} ; \mathrm{KH}_{2} \mathrm{PO}_{4}, 0.033 \mathrm{~g}$; yeast extract, $0.2 \mathrm{~g}$; trace element solution (Pfennig \& Lippert, 1966), $1 \mathrm{ml}$; vitamin solution (Wolin et al., 1963), $1 \mathrm{ml}$; resazurin, $1 \mathrm{mg}$; $\mathrm{NaHCO}_{3}, 0.5 \mathrm{~g} ; \mathrm{Na}_{2} \mathrm{~S} .9 \mathrm{H}_{2} \mathrm{O}, 0.5 \mathrm{~g} ;$ cysteine/ $\mathrm{HCl}, 0.5 \mathrm{~g}$. The medium was prepared anaerobically. $\mathrm{pH}$ was adjusted to $7 \cdot 0-7 \cdot 2$.

The effect of $\mathrm{pH}$ on growth was studied under a $\mathrm{CO}$ atmosphere in Medium 1 except that the phosphate component of the medium was added in the form of $0.01 \mathrm{M}$ phosphate buffer with a required $\mathrm{pH}$.

Sensitivity of strain $\mathrm{JM}^{\mathrm{T}}$ to penicillin $\left(50 \mu \mathrm{g} \mathrm{ml} \mathrm{m}^{-1}\right)$, ampicillin $\left(50 \mu \mathrm{g} \mathrm{ml}^{-1}\right)$, streptomycin $\left(50 \mu \mathrm{g} \mathrm{ml}^{-1}\right)$, kanamycin $\left(20 \mu \mathrm{g} \mathrm{ml}^{-1}\right)$ and neomycin $\left(20 \mu \mathrm{g} \mathrm{ml}^{-1}\right)$ was tested in cultures grown on $\mathrm{CO}$.

Temperature, $\mathrm{pH}$ and medium mineralization optima were determined from the growth rates. The cell density was measured by direct cell counting.

Analytical methods. Gaseous and liquid fermentation products were detected by GLC (Svetlichny et al., 1991a). Lactate was detected by GLC as acetaldehyde after periodic acid treatment of culture liquid samples (Teunissen et al., 1989)

DNA analyses. DNA was prepared as described by Marmur (1961). The DNA G + C content was determined by the melting point analysis (Marmur \& Doty, 1962) using Escherichia coli K-12 DNA as a reference.

The 16S rRNA gene from strain $\mathrm{JM}^{\mathrm{T}}$ was sequenced by the dideoxynucleotide chain termination method on an ABI 373A sequencer (Applied Biosystems). The $\mathrm{JM}^{\mathrm{T}}$ 16S rDNA sequence was manually aligned with $16 \mathrm{~S}$ rDNA sequences from closely related species obtained from the GenBank database. The initial sets of prealigned eubacterial sequences were obtained from the Ribosomal Databases Project (Larsen et al., 1993). Regions that either were not sequenced in one or more reference organisms or exhibited alignment uncertainty, i.e. positions 1-101, 201-218, 453-479, 839-847, 999-1035, 1134-1140, 1449-1455 and 1483-1486-3' terminus (E. coli numbering), were omitted from the analysis. Pairwise evolutionary distances (expressed as estimated changes per $100 \mathrm{nt}$ ) were computed as suggested by Jukes \& Cantor (1969) and Swofford \& Olsen (1990). A rooted phylogenetic tree was constructed by the neighbour-joining method (Saitou \& Nei, 1987) with the bootstrap analysis of 100 trees performed by using the TREECON program (Van de Peer \& De Wachter, 1994) using Streptomyces griseus as an outgroup.

Reference accession numbers of sequences used in this study are as follows: Thermoanaerobacter thermohydrosulfuricus DSM 567, L09161; Thermoanaerobacter sulfurophilus L-64 ${ }^{\mathrm{T}}$, Y16940; Thermoanaerobacter wiegelii Rt8.B1 ${ }^{\mathrm{T}}$, X92513; Thermoanaerobacter acetoethylicus ATCC 33265 ${ }^{\mathrm{T}}$, L09163; Thermoanaerobacter kivui DSM 2030 ${ }^{\mathrm{T}}$, L09160; Thermoanaerobacter brockii DSM 1457 ${ }^{\mathrm{T}}$, L09165; Thermoanaerobacter mathranii $\mathrm{A} 3^{\mathrm{T}}$, Y11279; Thermoanaerobacter thermocopriae JT-3 ${ }^{\mathrm{T}}$, L09167; Thermoanaerobacter ethanolicus JW200 ${ }^{\mathrm{T}}$, L09162; 'Thermoanaerobacter lacticus' SEBR 5268 U14330; Thermoanaerobacter siderophilus SR4 ${ }^{\mathrm{T}}$, AF120479; Thermoanaerobacterium thermosulfurigenes E100-69 ${ }^{\mathrm{T}}$, L09161; Thermoanaerobacterium aotearoense JW/SL- 

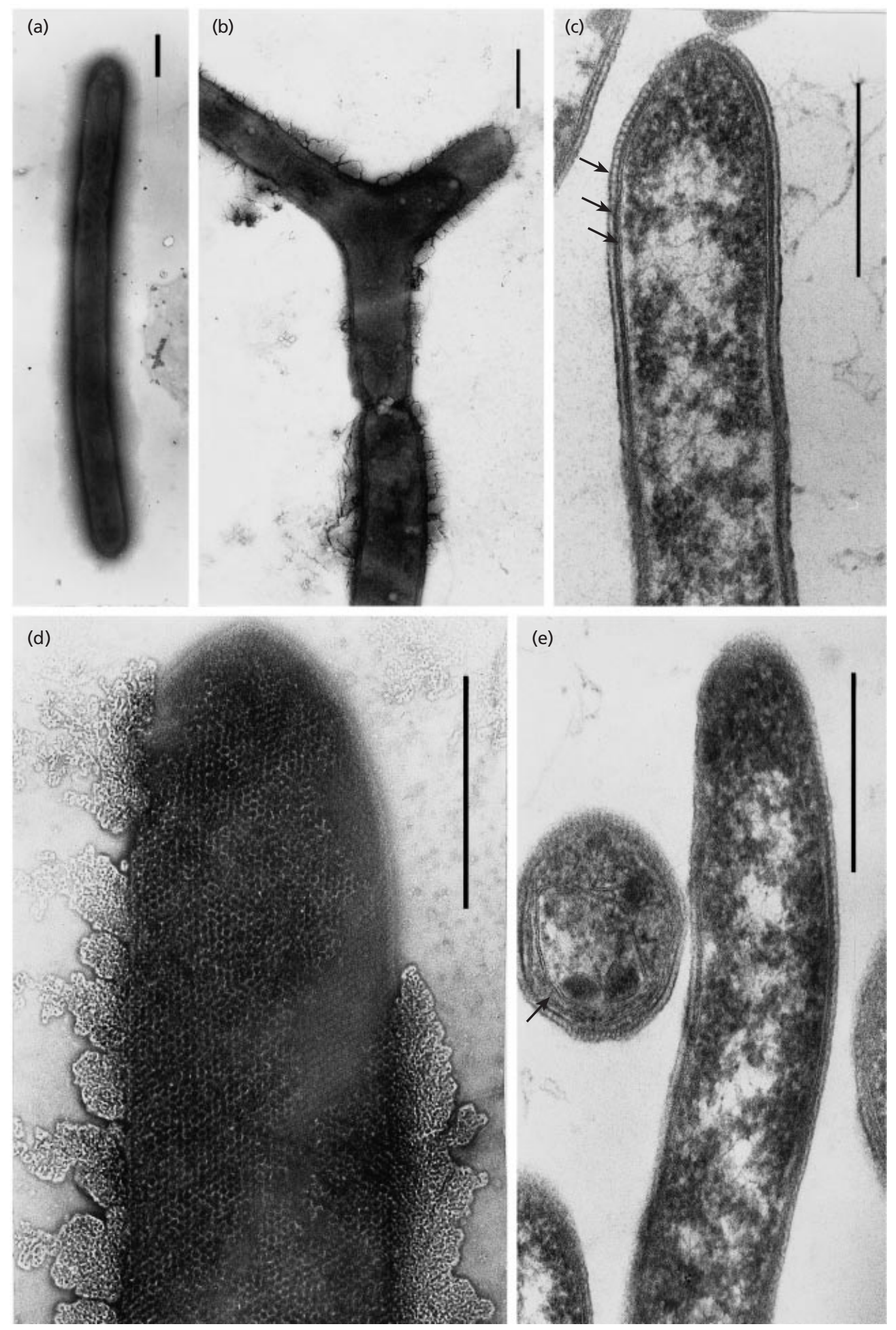

Fig. 1. Electron micrographs of cells of strain $\mathrm{JM}^{\top}$. $(a, b, d)$ Negative staining; $(c, e)$ thin sections. Bars $0.5 \mu \mathrm{m}$. Arrows in (c) indicate (from inside to outside) a cytoplasmic membrane, an electron-dense layer and an S-layer formed by global subunits. The arrow in (e) indicates an invaginated cytoplasmic membrane. 
$\mathrm{NZ613}^{\mathrm{T}}$; X93359; Thermoanaerobacterium saccharolyticum DSM 7060" L09169; Thermoanaerobacterium xylanolyticum DSM 7097 ${ }^{\mathrm{T}}$, L09172; Thermoanaerobacterium thermosaccharolyticum ATCC 7956 ${ }^{\mathrm{T}}$, M59119; Dictyoglomus thermophilum H-6-12 ${ }^{\mathrm{T}}$, X69194; Anaerobranca horikoshii JW/YL-138 ${ }^{\mathrm{T}}$, U21809; Moorella thermoautotrophica JW 701/5T, X58354; Moorella thermoacetica LJD $^{\mathrm{T}}$, X58352; Moorella glycerini YS6 ${ }^{\mathrm{T}}$, U82327; Thermoterrabacterium ferrireducens $\mathrm{JW} / \mathrm{AS}-\mathrm{Y}^{\mathrm{T}}$, U76363; Ammonifex degensii DSM 10501 ${ }^{\mathrm{T}}$, U34975; Syntrophospora bryantii DSM 3014B, M26491; Carboxydothermus hydrogenoformans DSM $6008^{\mathrm{T}}$, AF244579.

\section{RESULTS}

\section{Enrichment and isolation}

Bottles inoculated with mud samples were incubated at $55,60,70$ and $80^{\circ} \mathrm{C}$. Incubation at 55 and $60^{\circ} \mathrm{C}$ did not result in significant microbial growth or $\mathrm{CO}$ consumption. In the bottles incubated at $80{ }^{\circ} \mathrm{C}$ for $5 \mathrm{~d}$, $\mathrm{CO}$ consumption and hydrogen production were detected, but stable growth was not obtained. At $70{ }^{\circ} \mathrm{C}$, growth of thin rods was observed and the gas pressure in these bottles increased from 100 to 150-160 kPa after 4-5 d incubation. During growth, $\mathrm{CO}$ concentration dropped in the gas phase, whereas $\mathrm{H}_{2}$ and $\mathrm{CO}_{2}$ appeared. After a number of serial dilution transfers, homogeneous culture of long thin rods was obtained. Branching cells were observed. On solid medium under $\mathrm{CO}$, round, white, semitransparent colonies (up to $1 \mathrm{~mm}$ diam.) developed after $3 \mathrm{~d}$ of incubation at $70^{\circ} \mathrm{C}$. After several consequent isolations of a single colony, the pure culture of strain $\mathrm{JM}^{\mathrm{T}}$ was obtained.

\section{Morphology of the new isolate}

During growth on $\mathrm{CO}$, cells of isolate $\mathrm{JM}^{\mathrm{T}}$ were straight rods, about $0.4 \mu \mathrm{m}$ wide and from 4 to $10 \mu \mathrm{m}$ long (Fig. 1a). They appeared as single cells or short chains of three to five cells. Branching (Fig. 1b) was usually observed at the end of the exponential phase during growth on $\mathrm{CO}$. In the stationary phase, round bodies, probably spheroplasts, appeared at the ends of lysed cells or even separately. In media with organic substrates, cell length and branching frequency were substrate-dependent. Branching was not observed on glucose or cellobiose, but was frequent on galactose. Flagella were never observed. Electron microscopy of ultrathin sections revealed that the cell envelope was composed of the cytoplasmic membrane, an electrondense layer (Fig. 1c) and a hexagonal S-layer formed by global subunits (Fig. 1c, d, e). The cytoplasmic membrane was often invaginated and formed lamellalike structures (Fig. 1d)

\section{Growth characteristics}

Growth of isolate $\mathrm{JM}^{\mathrm{T}}$ occurred within a temperature range of $50-80^{\circ} \mathrm{C}$ with an optimum at $70^{\circ} \mathrm{C}$; no growth was observed at 40 or $85^{\circ} \mathrm{C}$. Strain $\mathrm{JM}^{\mathrm{T}}$ grew in a $\mathrm{pH}$ range of $5 \cdot 8-7 \cdot 6$, with an optimum at $6 \cdot 8-7 \cdot 2$.

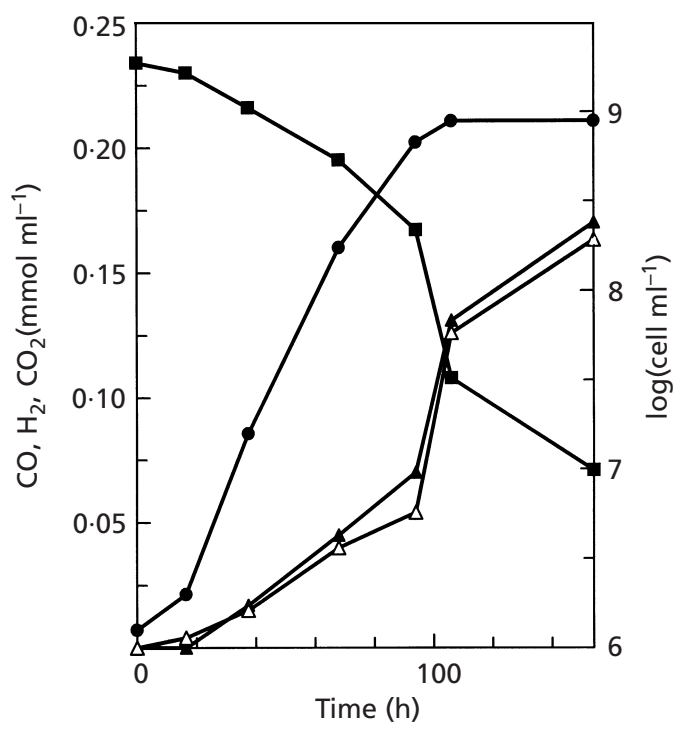

Fig. 2. Growth of strain $\mathrm{JM}^{\top}$ at $70^{\circ} \mathrm{C}$ in Medium 1 supplemented with $0.2 \mathrm{~g}$ yeast extract $\mathrm{I}^{-1}$ under a $\mathrm{CO}$ atmosphere ( $(\boldsymbol{O}), \mathrm{CO}$ consumption $(\boldsymbol{\square}), \mathrm{H}_{2}$ production $(\boldsymbol{\Delta})$ and $\mathrm{CO}_{2}$ production $(\triangle)$.

The optimum concentration of sea salts for strain $\mathrm{JM}^{\mathrm{T}}$ was between 20.5 and $25.5 \mathrm{~g}^{-1}$. Artificial seawater could not be replaced by corresponding concentrations of $\mathrm{NaCl}$. In Medium 2 supplemented with $0.5-5 \%$ $\mathrm{NaCl}$, no growth of strain $\mathrm{JM}^{\mathrm{T}}$ was observed.

Strain $\mathrm{JM}^{\mathrm{T}}$ grew only under strictly anaerobic conditions. It did not grow in Medium 1 without reducing agents, nor under the mixture of $\mathrm{CO}$ and air $(4: 1, \mathrm{v} / \mathrm{v})$. It grew in an atmosphere of $100 \% \mathrm{CO}$ in Medium 1 supplemented with $0.5 \mathrm{~g}$ yeast extract $1^{-1}$ with a final cell yield of $3 \times 10^{8}$ cells $\mathrm{ml}^{-1}$. When the concentration of yeast extract was increased up to $0 \cdot 2 \mathrm{~g}^{-1}$ the cell yield was $1 \times 10^{9}$ cells $\mathrm{ml}^{-1}$. CO oxidation was coupled with $\mathrm{H}_{2}$ and $\mathrm{CO}_{2}$ formation (Fig. 2). Methane, lactate, acetate or other volatile fatty acids were not formed during growth on $\mathrm{CO}$. The amount of hydrogen formed in control bottles with the same medium under $100 \% \mathrm{~N}_{2}$ did not exceed $1 \%$ of that formed in the presence of $\mathrm{CO}$. This suggests that $\mathrm{H}_{2}$ production is connected mainly with $\mathrm{CO}$ utilization. The stoichiometry of the reaction corresponded to an equimolar ratio of $\mathrm{CO}$ consumption and $\mathrm{H}_{2}$ and $\mathrm{CO}_{2}$ production (Fig. 2), according to the equation: $\mathrm{CO}+\mathrm{H}_{2} \mathrm{O} \rightarrow$ $\mathrm{H}_{2}+\mathrm{CO}_{2}$. The generation time of strain $\mathrm{JM}^{\mathrm{T}}$ under optimal conditions with $100 \% \mathrm{CO}$ in the gas phase and $0 \cdot 2 \mathrm{~g}$ yeast extract $1^{-1}$ was $7 \cdot 1 \mathrm{~h}$. Yeast extract could be replaced by $0.2 \mathrm{~g}$ peptone or acetate $1^{-1}$ with the same effect. Peptone or acetate supported stable growth of isolate $\mathrm{JM}^{\mathrm{T}}$ under a $\mathrm{CO}$ atmosphere over at least five transfers.

Apart from $\mathrm{CO}$, strain $\mathrm{JM}^{\mathrm{T}}$ was able to grow on peptone, yeast extract, starch, cellobiose, glucose, galactose, fructose and pyruvate, but not on sucrose. 


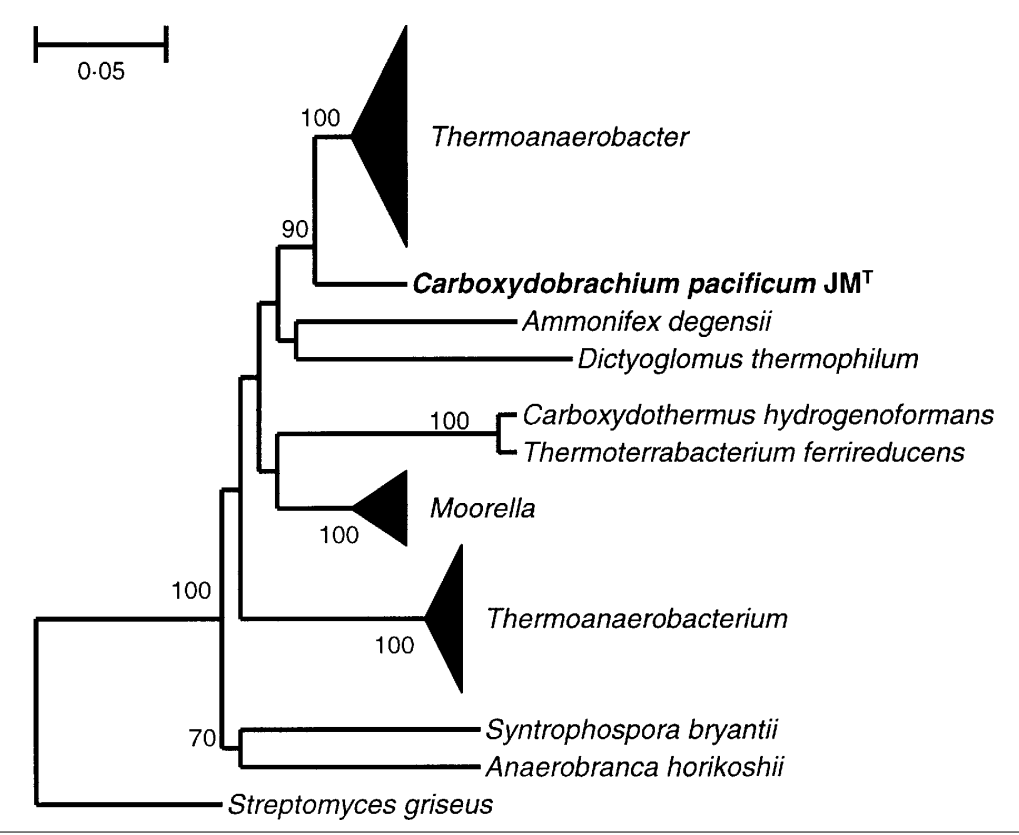

Fig. 3. Dendrogram showing the phylogenetic position of strain $\mathrm{JM}^{\top}$. The tree was derived by Jukes \& Cantor (1969) distance analysis. Bar represents $5 \mathrm{nt}$ substitutions per $100 \mathrm{nt}$. Numbers refer to bootstrap values.
The products of organotrophic growth were $\mathrm{H}_{2}$, acetate and $\mathrm{CO}_{2}$. Among organic substrates, galactose supported the best growth of strain $\mathrm{JM}^{\mathrm{T}}$, with a doubling time of about $10 \mathrm{~h}$. Acetate, $\mathrm{CO}_{2}$ and hydrogen were produced from galactose in a $2: 1: 1$ ratio. An $\mathrm{H}_{2} / \mathrm{CO}_{2}$ gas mixture $(4: 1, \mathrm{v} / \mathrm{v})$ did not support growth. No growth was observed on acetate, formate, methanol, ethanol or lactate in the presence or absence of elemental sulfur or sulfate.

Penicillin did not inhibit growth, $\mathrm{CO}$ consumption and $\mathrm{H}_{2} / \mathrm{CO}_{2}$ production; ampicillin, streptomycin, kanamycin and neomycin completely inhibited both growth and $\mathrm{CO}$ utilization.

\section{DNA base composition}

The DNA $\mathrm{G}+\mathrm{C}$ content of strain $\mathrm{JM}^{\mathrm{T}}$ was $33 \pm 1 \mathrm{~mol} \%$.

\section{Phylogenetic analysis}

A total of $1490 \mathrm{nt}$ of the $16 \mathrm{~S}$ rRNA gene of strain $\mathrm{JM}^{\mathrm{T}}$, corresponding to positions 8-1512 (E. coli numbering) were sequenced. A total of 78 sequences of representative species from various phyla of the Bacteria domain were compared with the sequence of strain $\mathrm{JM}^{\mathrm{T}}$. This analysis revealed that strain $\mathrm{JM}^{\mathrm{T}}$ is a member of the low-G $+\mathrm{C}$, Gram-positive phylum and falls into the 'Thermoanaerobacter and relatives' group (RDP database). Additional sequence alignments and phylogenetic analysis performed with members of this group revealed that strain $\mathrm{JM}^{\mathrm{T}}$ was related to species of the genus Thermoanaerobacter (sequence similarity of $92 \cdot 3-93 \cdot 5 \%$ ). However, this value was lower than the interspecies level of similarity within the phylogenetic cluster of the genus Thermoanaerobacter
$(94 \cdot 7-99 \cdot 4 \%)$. The level of sequence similarity with other members of this group was no more than $89 \cdot 1 \%$. A phylogenetic dendrogram showing these results is presented in Fig. 3. Bootstrap values indicate that the relationship of strain $\mathrm{JM}^{\mathrm{T}}$ to Thermoanaerobacter species is not robust $(90 \%)$. The thermophilic strain $\mathrm{JM}^{\mathrm{T}}$ shows a relatively high $\mathrm{G}+\mathrm{C}$ level in the $16 \mathrm{~S}$ rDNA gene, i.e. $58.8 \mathrm{~mol} \%$, which falls into the characteristic range for Thermoanaerobacter species. The transversion distance method (Woese et al., 1991; Swofford \& Olsen, 1990) for the generation of phylogenetic trees revealed that the high $\mathrm{G}+\mathrm{C}$ content of rDNA has introduced bias, resulting in the clustering of the members of the Thermoanaerobacter group. In this tree, strain $\mathrm{JM}^{\mathrm{T}}$ is not clustered together with Thermoanaerobacter species or other reference species (data not shown).

The relatedness of strain $\mathrm{JM}^{\mathrm{T}}$ and the genus Thermoanaerobacter was supported by the presence of specific oligonucleotide motifs at positions 841-846 and 998-1025 (E. coli numbering). To determine the affiliation of strain $\mathrm{JM}^{\mathrm{T}}$ with genera of the Thermoanaerobacter group, its $16 \mathrm{~S}$ rDNA was analysed for the presence of genus-specific signature nucleotides. The genera Thermoanaerobacter, Thermoanaerobacterium and Moorella can be defined by unique $16 \mathrm{~S}$ rDNA signature nucleotides at 50 sites in the gene (Rainey et al., 1993). Strain JM ${ }^{\mathrm{T}}$ has seven differences at signature positions with Thermoanaerobacter species and no less than 16 differences with other genera of this group.

Comparison of secondary structures of $16 \mathrm{~S}$ rRNAs of thermophilic members of the genus Thermoanaerobacter with those reported for other prokaryotes revealed the presence of unique helixes in four sequence 
regions (Rainey et al., 1993; Slobodkin et al., 1999). The secondary structure that is specific for the genus Thermoanaerobacter in these regions was not found in strain $\mathrm{JM}^{\mathrm{T}}$. Hence, on the basis of phylogenetic analysis, strain $\mathrm{JM}^{\mathrm{T}}$ does not belong to the Thermoanaerobacter cluster and should be considered as a separate phylogenetic branch.

\section{DISCUSSION}

$\mathrm{CO}$ can be used as a growth substrate by many metabolically and phylogenetically diverse prokaryotic micro-organisms. $\mathrm{O}_{2}$-dependent $\mathrm{CO}$ oxidation is a well known process carried out by a voluminous group of aerobic carboxydobacteria (Zavarzin, 1978; Meyer et al., 1993).

Among anaerobes, utilization of $\mathrm{CO}$ occurs via the acetyl-CoA pathway found in homoacetogenic bacteria (Ljungdahl, 1994), methanogenic (Deppenmeier et al., 1996; Ferry, 1999) and non-methanogenic archaea (Möller-Zinkhan \& Thauer, 1990; Vorholt et al., 1995, 1997), sulfate-reducing bacteria (Schauder et al., 1987; Janssen \& Schink, 1995; Elferink et al., 1999; Fukui et al., 1999) and photosynthetic bacteria (Uffen, 1983; Ensign, 1995). Some of the organisms possessing the acetyl-CoA pathway are able to utilize $\mathrm{CO}$ as an energy substrate during growth. During growth on $\mathrm{CO}$, homoacetogenic and methanogenic bacteria produce acetate and methane, respectively. Several acetogens produce, apart from acetate, other volatile fatty acids or alcohols during growth on $\mathrm{CO}$. Anaerobic oxidation of $\mathrm{CO}$ to $\mathrm{CO}_{2}$ with concurrent formation of $\mathrm{H}_{2}$ from water is another catabolic reaction which has been found so far only in two groups of microorganisms: mesophilic purple bacteria (Uffen, 1976; Dashekvicz \& Uffen, 1979; Kerby et al., 1995) and extremely thermophilic bacteria of the genus Carboxydothermus (Svetlichny et al., 1991a, 1994). Strain JM ${ }^{\mathrm{T}}$ carried out the same process of anaerobic $\mathrm{CO}$ oxidation coupled with only $\mathrm{CO}_{2}$ and $\mathrm{H}_{2}$ production as the representatives of the genus Carboxydothermus and was found to be a thermophile growing in the temperature range from 50 to $80^{\circ} \mathrm{C}$. Carboxydothermus hydrogenoformans (Svetlichny et al., 1991a) was isolated from freshwater hot springs and grows only chemolithotrophically with $\mathrm{CO}$ or chemoorganotrophically with pyruvate. Another thermophilic obligately carboxydotrophic bacterium, Carboxydothermus restrictus, was isolated from a freshwater hydrothermal vent at Raoul Island (Archipelago Kermadek, New Zealand) and grows only chemolithotrophically with CO (Svetlichny et al., 1994). Unidentified thermophilic anaerobic bacteria performing the reaction of $\mathrm{CO}$ oxidation to $\mathrm{CO}_{2}$ with concurrent $\mathrm{H}_{2}$ production from water are widely distributed in terrestrial hydrothermal springs of the Kuril Islands (Svetlichny et al., 1991b) and the Kamchatka Peninsula (Bonch-Osmolovskaya et al., 1999). There is also the evidence of the presence of such organisms in shallow-water submarine hot vents of the
Kuril Islands (Svetlichny et al., 1991b). Strain JM ${ }^{\mathrm{T}}$ is the first anaerobic marine organism growing on $\mathrm{CO}$ and producing hydrogen from water which has been isolated in pure culture. It was obtained from a deepsea hot vent and its growth was dependent on salt concentrations similar to those found in seawater. Strain $\mathrm{JM}^{\mathrm{T}}$ differs from previously known anaerobic CO-utilizing hydrogen-producing thermophiles both in morphological and physiological characteristics. Whereas cells of Carboxydothermus spp. are short motile rods, the new isolate has long non-motile branching cells. Another important differentiating feature of strain $\mathrm{JM}^{\mathrm{T}}$ is the wide range of growth substrates. In addition to lithoheterotrophic growth with $\mathrm{CO}$, it can grow organotrophically on different fermentable substrates, though with a lower growth rate than on $\mathrm{CO}$.

The $16 \mathrm{~S}$ rDNA sequence analysis places strain $\mathrm{JM}^{\mathrm{T}}$ in the Gram-positive Bacillus-Clostridium subphylum. Strain $\mathrm{JM}^{\mathrm{T}}$ appears to be related to the genus Thermoanaerobacter but does not belong to it. Morphologically, strain $\mathrm{JM}^{\mathrm{T}}$ differs from the representatives of genus Thermoanaerobacter by the ability to form branching cells. Anaerobranca horikoshii (Engle et al., 1995) also forms branching cells but is quite distant phylogenetically (Fig. 3). The main physiological feature that separates strain $\mathrm{JM}^{\mathrm{T}}$ from its closest relatives is that it grows rapidly on $\mathrm{CO}$, producing only $\mathrm{CO}_{2}$ and $\mathrm{H}_{2}$. Among its relatives only Thermoanaerobacter kivuii, Moorella thermoautotrophica and Moorella thermoacetica can grow on $\mathrm{CO}$ with acetate as the end product. The insufficient level of sequence similarity $(<93.5 \%)$ and the peculiarities of signature positions and secondary structure of $16 \mathrm{~S}$ rDNA sequence confirm the phenotypic evidence supporting that strain $\mathrm{JM}^{\mathrm{T}}$ should be considered as separate from the members of the Thermoanaerobacter group at a generic level.

Based on morphological, physiological and phylogenetic features of the isolate $\mathbf{J M}^{\mathrm{T}}$, we propose the description of a new genus, Carboxydobrachium, with the type species Carboxydobrachium pacificum gen. nov., sp. nov.

\section{Description of Carboxydobrachium gen. nov.}

Carboxydobrachium (Car.bo.xy.do.bra'chi.um. N.L. neut. n. Carboxydum carbon monoxide; N.L. neut. n. brachium arm, branch; N.L. neut. n. Carboxydobrachium $\mathrm{CO}$ branch, i.e. CO-utilizing, branching bacterium).

Cells are long, thin, non-motile branching rods. The Gram-positive cell wall is covered with an S-layer. Obligate anaerobe. Thermophile. Obligately requires seawater-based medium. Grows chemolithotrophically on $\mathrm{CO}$. Utilizes $\mathrm{CO}$ as the sole energy source with equimolar formation of $\mathrm{H}_{2}$ and $\mathrm{CO}_{2}$ according to the equation $\mathrm{CO}+\mathrm{H}_{2} \mathrm{O} \rightarrow \mathrm{CO}_{2}+\mathrm{H}_{2}$. Grows organotrophically on a number of fermentable substrates, 
producing $\mathrm{H}_{2}, \mathrm{CO}_{2}$ and acetate. The type species is Carboxydobrachium pacificum.

\section{Description of Carboxydobrachium pacificum sp. nov.}

Carboxydobrachium pacificum (pa.ci'fi.cum. L. neut. adj. pacificum peaceful, pertaining to the Pacific Ocean, from the western part of which the type strain was isolated).

Cells are long thin straight non-motile rods, of about $0 \cdot 3 \mu \mathrm{m}$ width and $4-10 \mu \mathrm{m}$ length. Cells are single or form short chains of three to five cells. Cells sometimes branch. Cells have a Gram-positive cell wall covered with an S-layer. On solid medium, round, white, translucent colonies are produced. Obligate anaerobe. Extreme thermophile. Grows within the temperature range of $50-80{ }^{\circ} \mathrm{C}$; optimum growth at $70^{\circ} \mathrm{C}$. $\mathrm{pH}$ for growth ranges from 5.8 to $7 \cdot 6$; optimum $\mathrm{pH}$ is $6 \cdot 8-7 \cdot 2$. Growth and $\mathrm{CO}$ consumption are not inhibited by penicillin, but ampicillin, streptomycin, kanamycin and neomycin completely inhibit growth and $\mathrm{CO}$ utilization. Obligately requires seawater-based medium. The optimum concentration of sea salts is $20 \cdot 5-25 \cdot 5 \mathrm{~g}^{-1}$. Grows chemolithotrophically on CO. Utilizes $\mathrm{CO}$ as the sole energy source with equimolar formation of $\mathrm{H}_{2}$ and $\mathrm{CO}_{2}$ according to the equation $\mathrm{CO}+\mathrm{H}_{2} \mathrm{O} \rightarrow \mathrm{CO}_{2}+\mathrm{H}_{2}$. Requires yeast extract or peptone or acetate as carbon source. Grows organotrophically on peptone, yeast extract, starch, cellobiose, glucose, galactose, fructose and pyruvate, but not on sucrose. The products of organotrophic growth are acetate, $\mathrm{CO}_{2}$ and $\mathrm{H}_{2}$. An $\mathrm{H}_{2} / \mathrm{CO}_{2}$ gas mixture does not support growth. No growth occurs on acetate, formate, methanol, ethanol or lactate either in the presence or in the absence of elemental sulfur or sulfate. DNA G + C content is $33 \pm 1 \mathrm{~mol} \%$. The type strain is Carboxydobrachium pacificum $\mathrm{JM}^{\mathrm{T}}$ (= DSM $12653^{\mathrm{T}}$ ), isolated from a submarine hydrothermal vent in Okinawa Trough.

\section{ACKNOWLEDGEMENTS}

The authors are grateful to G. A. Zavarzin and A. V. Lebedinsky, Institute of Microbiology, Russian Academy of Sciences, for helpful discussions. This work was supported by the Russian Foundation for Basic Research, grants nos 96-04-49463 and 99-04-48360, the 'Biodiversity' program of the Russian Ministry of Science and Technology, a NATO CLG grant to T. S. and F. T. R. and by NSF LEXEN Program support to F. T. R. and J. M. G.

\section{REFERENCES}

Antoine, E., Cilla, V., Meunier, J. R., Guezennec, J., Lesongeur, F. \& Barbier, G. (1997). Thermosipho melanesiensis sp. nov., a new thermophilic anaerobic bacterium belonging to the order Thermotogales, isolated from deep-sea hydrothermal vents in the South-western Pacific Ocean. Int J Syst Bacteriol 47, 1118-1123.
Blöchl, E., Rachel, R., Burggraf, S., Hafenbradl, D., Jannasch, H. W. \& Stetter, K. O. (1997). Pyrolobus fumarii, gen. and sp. nov., represents a novel group of archaea, extending the upper temperature limit for life to $113{ }^{\circ} \mathrm{C}$. Extremophiles 1, 14-21.

Bonch-Osmolovskaya, E. A., Miroshnichenko, M. L., Slobodkin, A. I. \& 7 other authors (1999). Distribution and biodiversity of anaerobic lithotrophic prokaryotes in terrestrial hydrotherms of Kamchatka. Microbiology (English translation of Mikrobiologiya) 68, 343-351.

Burggraf, S., Jannasch, H. W., Nicolaus, B. \& Stetter, K. O. (1990). Archaeoglobus profundus sp. nov., represents a new species within the sulfate-reducing Archeabacteria. Syst Appl Microbiol 13, 24-28.

Dashekvicz, M. P. \& Uffen, R. L. (1979). Identification of carbon monoxide-metabolizing bacterium as a strain of Rhodopseudomonas gelatinosa (Molish) van Niel. Int J Syst Bacteriol 29, 145-148.

Deppenmeier, U., Muller, V. \& Gottschalk, G. (1996). Pathways of energy conservation in methanogenic archaea. Arch Microbiol 165, 149-163.

Elferink, S. J. W. H. O., Akkermans-van Vliet, W. M., Bogte, J. J. \& Stams, A. J. M. (1999). Desulfobacca acetoxidans gen. nov., sp. nov., a novel acetate-degrading sulfate reducer isolated from sulfidogenic granular sludge. Int J Syst Bacteriol 49, 345.

Engle, M., Li, Y., Woese, C. \& Wiegel, J. (1995). Isolation and characterization of a novel alkalitolerant thermophile, Anaerobranca horikoshii gen. nov., sp. nov. Int J Syst Bacteriol 45, 454-461.

Ensign, S. A. (1995). Reactivity of carbon monoxide dehydrogenase from Rhodospirillum rubrum with carbon dioxide, carbonyl sulfide, and carbon disulfide. Biochemistry 34, 5372-5381.

Erauso, G., Reysenbach, A. L., Godfroy, A. \& 8 other authors (1993). Pyrococcus abyssi sp. nov., a new hyperthermophilic archaeon isolated from a deep-sea hydrothermal vent. Arch Microbiol 160, 338-349.

Ferry, J. G. (1999). Enzymology of one-carbon metabolism in methanogenic pathways. FEMS Microbiol Rev 23, 13-38.

Fiala, G., Stetter, K. O., Jannasch, H. W., Langworthy, T. A. \& Madon, J. (1986). Staphylothermus marinus sp. nov. represents a novel genus of extremely thermophilic submarine heterotrophic archaebacteria growing up to $98^{\circ} \mathrm{C}$. Syst Appl Microbiol 8, 106-113.

Fukui, M., Teske, A., Assmus, B., Muyzer, G. \& Widdel, F. (1999). Physiology, phylogenetic relationships, and ecology of filamentous sulfate-reducing bacteria (genus Desulfonema). Arch Microbiol 172, 193-203.

González, J. M., Kato, C. \& Horikoshi, K. (1995). Thermococcus peptonophilus sp. nov., a fast growing, extremely thermophilic archaebacterium isolated from deep-sea hydrothermal vents. Arch Microbiol 164, 159-164.

González, J. M., Masuchi, Y., Robb, F. T., Ammerman, J. W., Maeder, D. L., Yanagibayashi, M., Tamaoka, J. \& Kato, C. (1998). Pyrococcus horikoshii sp. nov., a hyperthermophilic archaeon isolated from a hydrothermal vent at the Okinawa Trough. Extremophiles 2, 123-130.

Huber, R., Jannasch, H. W., Rachel, R., Fuchs, T. \& Stetter, K. O. (1997). Archaeoglobus veneficus sp. nov., a novel facultative chemolithoautotrophic hyperthermophilic sulfite reducer, isolated from abyssal black smokers. Syst Appl Microbiol 20, 374-380. 
Jannasch, H. W. (1995). Microbial interactions with hydrothermal fluids. In Seafloor Hydrothemal Systems: Physical, Chemical, Biological, and Geological Interactions. Geophysical Monograph 91, pp. 273-296. Washington, DC: American Geophysical Union.

Janssen, P. H. \& Schink, B. (1995). Metabolic pathways and energetics of the acetone-oxidizing, sulfate-reducing bacterium, Desulfobacterium cetonicum. Arch Microbiol 163, 188-194.

Jeanthon, C., L'Haridon, S., Reysenbach, A.-L., Vernet, M., Messner, P., Sleytr, U. \& Prieur, D. (1998). Methanococcus infernus sp. nov., a novel hyperthermophilic lithotrophic methanogen isolated from a deep-sea hydrothermal vent. Int J Syst Bacteriol 48, 913-919.

Jones, W. J., Leigh, J. A., Mayer, F., Woese, C. R. \& Wolfe, R. S. (1983). Methanococcus jannaschii sp. nov., an extremely thermophilic methanogen from a submarine hydrothermal vent. Arch Microbiol 136, 254-261.

Jukes, T. H. \& Cantor, C. R. (1969). Evolution of protein molecules. In Mammalian Protein Metabolism, pp. 21-132. Edited by H. N. Munro. New York: Academic Press.

Kerby, R. L., Ludden, P. W. \& Roberts, G. P. (1995). Carbon monoxide-dependent growth of Rhodospirillum rubrum. $J$ Bacteriol 177, 2241-2244.

Kobayashi, T., Kwak, Y. S., Akiba, T., Kudo, T. \& Horikoshi, K. (1994). Thermococcus profundus sp. nov., a new hyperthermophilic archaeon isolated from a deep-sea hydrothermal vent. Syst Appl Microbiol 17, 232-236.

Kurr, M., Huber, R., König, H., Jannasch, H. W., Fricke, H., Trincone, A., Kristjansson, J. K. \& Stetter, K. O. (1991). Methanopyrus kandleri, gen. and sp. nov. represents a novel group of hyperthermophilic methanogens, growing at $110^{\circ} \mathrm{C}$. Arch Microbiol 156, 239-247.

Larsen, N., Olsen, G. J., Maidak, B. L., McCaughey, M. J., Overbeek, R., Macke, T. J., Marsh, T. L. \& Woese, C. R. (1993). The Ribosomal Database Project. Nucleic Acids Res 21, 3021-3023.

L'Haridon, S., Cilia, V., Messner, P., Raguénès, G., Gambacorta, A., Sleytr, U. B., Prieur, D. \& Jeanthon, C. (1998). Desulfurobacterium thermolithotrophum gen. nov., sp. nov., a novel autotrophic sulphur-reducing bacterium isolated from a deepsea hydrothermal vent. Int J Syst Bacteriol 48, 701-711.

Ljungdahl, L. G. (1994). The acetyl-CoA pathway and the chemiosmotic generation of ATP during acetogenesis. In Acetogenesis, pp. 65-87. Edited by H. Drake. New York: Chapman \& Hall.

Marmur, J. (1961). A procedure for the isolation of desoxyribonucleic acid from microorganisms. J Mol Biol 3, 208-218.

Marmur, J. \& Doty, P. (1962). Determination of the base composition of deoxyribonucleic acid from its thermal denaturation temperature. $J$ Mol Biol 5, 109-118.

Marteinsson, V. T., Birrien, J. L., Kristjansson, J. K. \& Prieur, D. (1995). First isolation of thermophilic aerobic non-sporulating heterotrophic bacteria from deep-sea hydrothermal vents. FEMS Microbiol Ecol 18, 163-174.

Marteinsson, V. T., Birrien, J. L. \& Prieur, D. (1996a). In situ enrichment and isolation of thermophilic microorganisms from deep-sea hydrothermal environments. Can J Microbiol 43, 694-697.

Marteinsson, V. T., Birrien, J. L., Jeanthon, C. \& Prieur, D. (1996b). Numerical taxonomic study of thermophilic Bacillus isolated from three geographically separated deep-sea hydrothermal vents. FEMS Microb Ecol 21, 255-266.

Meyer, O., Frunzke, K. \& Morsdorf, G. (1993). Biochemistry of aerobic utilization of carbon monoxide. In Microbial Growth on $C_{1}$ Compounds, pp. 433-459. Edited by J. C. Murrell \& D. P. Kelly. Andover: Intercept.

Möller-Zinkhan, D. \& Thauer, R. K. (1990). Anaerobic lactate oxidation to $3 \mathrm{CO}_{2}$ by Archaeoglobus fulgidus via the carbon monoxide dehydrogenase pathway: demonstration of the acetyl-CoA carbon-carbon cleavage reaction in cell extracts. Arch Microbiol 153, 213-218.

Pfennig, N. \& Lippert, K. D. (1966). Uber das Vitamin $\mathrm{B}_{12}$ Bedurfnis phototropher Schwefelbacterien. Arch Microbiol 55, 245-246.

Pley, U., Schipka, J., Gambacorta, A., Jannasch, H. W., Fricke, H., Rachel, R. \& Stetter, K. O. (1991). Pyrodictium abyssi sp. nov. represents a novel heterotrophic marine Archaeal hyperthermophile growing at $110^{\circ} \mathrm{C}$. Syst Appl Microbiol 14, 245-243.

Prieur, D., Erauso, G. \& Jeanthon, C. (1995). Hyperthermophilic life at deep-sea hydrothermal vents. Planet Space Sci $\mathbf{4 3}$, 115-122.

Rainey, F. A., Ward, N. L., Morgan, H. W., Toalster, R. \& Stackebrandt, E. (1993). Phylogenetic analysis of anaerobic thermophilic bacteria: aid for their reclassification. J Bacteriol 175, 4772-4779.

Saitou, N. \& Nei, M. (1987). The neighbor-joining method: a new method for reconstructing phylogenetic trees. Mol Biol Evol 4, 406-425.

Sakai, H., Gamo, T., Kim, E.-S. \& 10 other authors (1990). Unique chemistry of the hydrothermal solution in the mid-Okinawa Trough back arc basin. Geophys Res Lett 17, 2133-2136.

Schauder, R., Widdel, F. \& Fuchs, G. (1987). Carbon assimilation pathways in sulfate-reducing bacteria. II. Enzymes of a reductive citric acid cycle in the autotrophic Desulfurobacter hydrogenophilus. Arch Microbiol 148, 218-225.

Slobodkin, A. l., Tourova, T. P., Kuznetsov, B. B., Kostrikina, N. A., Chernyh, N. A. \& Bonch-Osmolovskaya, E. A. (1999). Thermoanaerobacter siderophilus sp. nov., a novel dissimilatory $\mathrm{Fe}(\mathrm{III})$-reducing, anaerobic, thermophilic bacterium. Int J Syst Bacteriol 49, 1471-1478.

Svetlichny, V. A., Sokolova, T. G., Gerhardt, M., Ringpfeil, M., Kostrikina, N. A. \& Zavarzin, G. A. (1991a). Carboxydothermus hydrogenoformans gen. nov., sp. nov., a CO-utilizing thermophilic anaerobic bacterium from hydrothermal environments of Kunashir Island. Syst Appl Microbiol 14, 254-260.

Svetlichny, V. A., Sokolova, T. G., Gerhardt, M., Kostrikina, N. A. \& Zavarzin, G. A. (1991b). Anaerobic extremely thermophilic carboxydotrophic bacteria in hydrotherms of Kuril Islands. Microb Ecol 21, 1-10.

Svetlichny, V. A., Sokolova, T. G., Kostrikina, N. A. \& Lysenko, A. M. (1994). A new thermophilic anaerobic carboxydotrophic bacterium Carboxydothermus restrictus sp. nov. Microbiology (English translation of Mikrobiologiya) 3, 523-528.

Swofford, D. L. \& Olsen, G. J. (1990). Phylogeny reconstruction. In Molecular Systematics, pp. 411-501. Edited by D. M. Hillis \& C. Moritz. Sunderland: Sinauer Associates.

Teunissen, M. J., Marras, S. A. E., Op den Camp, H. J. M. \& Vogels, G. D. (1989). Improved method for simultaneous determination of alcohols, volatile fatty acids, lactic acid or 2,3butanediol in biological samples. J Microbiol Methods 10, 247-254.

Uffen, R. L. (1976). Anaerobic growth of Rhodopseudomonas species in the dark with carbon monoxide as sole carbon and energy substrate. Proc Natl Acad Sci US A 73, 3298-3302. 
Uffen, R. L. (1983). Metabolism of carbon monoxide by Rhodopseudomonas gelatinosa: cell growth and properties of the oxidation system. J Bacteriol 155, 956-965.

Van de Peer, Y. \& De Wachter, R. (1994). TREECON for Windows: a software package for the construction and drawing of evolutionary trees for the Microsoft Windows environment. Comput Applic Biosci 10, 569-570.

Vorholt, J., Kunow, J., Stetter, K. O. \& Thauer, R. K. (1995). Enzymes and coenzymes of the carbon monoxide dehydrogenase pathway for autotrophic $\mathrm{CO}_{2}$ fixation in Archaeoglobus lithotrophicus and the lack of carbon monoxide dehydrogenase in heterotrophic A. profundus. Arch Microbiol 163, 112-118.
Vorholt, J. A., Hafenbradl, D., Stetter, K. O. \& Thauer, R. K. (1997). Pathways of autotrophic $\mathrm{CO}_{2}$ fixation and of dissimilatory nitrate reduction to $\mathrm{N}_{2} \mathrm{O}$ in Ferroglobus placidus. Arch Microbiol 167, 19-23.

Woese, C. R., Achenbach, L., Rouviere, P. \& Mandelco, L. (1991). Archaeal phylogeny: re-examination of the phylogenetic position of Archaeoglobus fulgidus in light of certain compositioninduced artifacts. Syst Appl Microbiol 14, 364-371.

Wolin, E. A., Wolin, M. J. \& Wolfe, R. S. (1963). Formation of methane by bacterial extracts. J Biol Chem 238, 2882-2886.

Zavarzin, G. A. (1978). Hydrogen-Oxidizing and Carboxydobacteria. Moscow: Nauka (in Russian). 